慶應義塾大学学術情報リポジトリ

Keio Associated Repository of Academic resouces

\begin{tabular}{|c|l|}
\hline Title & $\begin{array}{l}\text { Formation of a thiamine disulfide complex with fatty acid mechanism of formation of the } \\
\text { complex }\end{array}$ \\
\hline Sub Title & \\
\hline Author & $\begin{array}{l}\text { 小股, 泰子(Komata, Yasuko) } \\
\text { 藤江, 忠雄(Fujie, Tadao) } \\
\text { 金子, 明子(Kaneko, Akiko) } \\
\text { 上田, 文雄(Ueda, Fumio) } \\
\text { 浦野, 四郎(Urano, Shiro) }\end{array}$ \\
\hline Publisher & 共立薬科大学 \\
\hline Publication year & 1988 \\
\hline Jtitle & $\begin{array}{l}\text { 共立薬科大学研究年報 (The annual report of the Kyoritsu College of } \\
\text { Pharmacy). No.33 (1988. ),p.182-182 }\end{array}$ \\
\hline JaLC DOI & \\
\hline Abstract & \\
\hline Notes & 抄録 \\
\hline Genre & Technical Report \\
\hline URL & https://koara.lib.keio.ac.jp/xoonips/modules/xoonips/detail.php?koara_id=AN00062898-0000003 \\
\hline & $3-0182$ \\
\hline
\end{tabular}

慶應義塾大学学術情報リポジトリ(KOARA)に掲載されているコンテンツの著作権は、それぞれの著作者、学会または出版社/発行者に帰属し、その権利は著作権法によって 保護されています。引用にあたっては、著作権法を遵守してご利用ください。

The copyrights of content available on the KeiO Associated Repository of Academic resources (KOARA) belong to the respective authors, academic societies, or publishers/issuers, and these rights are protected by the Japanese Copyright Act. When quoting the content, please follow the Japanese copyright act. 
No. 33 (1988)

\title{
Formation of a Thiamine Disulfide Complex with Fatty Acid Mechanism of Formation of the Complex
}

\author{
Yasuko Komata, Tadao Fujie, Akiko Kaneko, Fumio UedA*, \\ and Shiro URANo** \\ 小股泰子，藤江忠雄，金子明子，上田文雄 ${ }^{*}$, 浦野四郎 ${ }^{* *}$
}

The formation of complexes between thiamine disulfide (TDS) or O-acetyl thiamine disulfide (O-acetyl TDS) and fatty acid or fatty acid methyl ester in methanol has been studied by fluorescence quenching and ${ }^{13} \mathrm{C}-\mathrm{NMR}$ relaxation $\left(\mathrm{T}_{1}\right)$ measurements. The association constants ( $\mathrm{K}$ values) of TDS and O-acetyl TDS with fatty acids (from $11: 0$ to $18: 0$, and $18: 1,18: 2,18: 3,20: 4$ ) and fatty acid methyl esters have been determined. These values do not depend on either the number of carbon atoms or the degree of unsaturation of the fatty acid. The $\mathrm{K}$ values of TDS and O-acetyl TDS with fatty acid were $7.8 \mathrm{M}^{-1}$ and $5.1 \mathrm{M}^{-1}$, respectively. The $\mathrm{K}$ values of TDS and $\mathrm{O}$-acetyl TDS with fatty acid methyl ester were very small. These results show that the $-\mathrm{OH}$ moiety in TDS and the $-\mathrm{COOH}$ moiety in the fatty acid are necessary for formation of the complex.

* 本報告は Lipids, 23 (6), 525-527 (1988) に発表.

* Research Laboratory, Kawai Seiyaku Co., Ltd.

** Tokyo Metropolitan Institute of Gerontology 